\title{
Public's Experiences and Expectations of Pharmacists during Coronavirus (COVID-19) in Saudi Arabia
}

\author{
Yousef Ahmed Alomi*, (D) BSC. \\ Pharm, MSc. Clin Pharm, BCPS, BCNSP, DiBA, \\ CDE \\ Critical Care Clinical Pharmacists, TPN Clinical \\ Pharmacist, Freelancer Business Planner, \\ Content Editor, and Data Analyst, Riyadh, \\ SAUDI ARABIA.
}

Sultan Mohammed Al-Jarallah, Head, Ambulatory Care Pharmacy, Oncology and Haematology Clinical Pharmacist,

Pharmaceutical Care Department, Security Forces Hospital, Riyadh, SAUDI ARABIA.

Dona Abdullah Alajmah, Pharm.

D, Batterjee Medical College, Jeddah, SAUDI ARABIA.

Shatha Alhassan Alnami, Pharm. D, Jazan University, Jazan, SAUDI ARABIA.

\section{Correspondence:}

Dr. Yousef Ahmed Alomi, Bsc. Pharm, Msc Clin pharm, BCPS, BCNSP, DiBA, CDE Critical Care Clinical Pharmacists, TPN Clinical Pharmacist, Freelancer Business Planner, Content Editor and Data Analyst, P.O.BOX 100, Riyadh 11392, Riyadh, SAUDI ARABIA

Phone no: +966 504417712

E-mail:yalomi@gmail.com
Received: 13-12-2020;

Accepted: 20-02-2021;

Copyright: () the author(s), publisher and licensee International Journal of Pharmacology and Clinical Sciences. This is an open-access article distributed under the terms of the Creative Commons

Attribution Non-Commercial License, which permits unrestricted non-commercial use, distribution, and reproduction in any medium, provided the original work is properly cited.

This is an open access article distributed under the terms of the Creative Commons AttributionNonCommercial-ShareAlike 4.0 License

Access this article online

\begin{tabular}{|c|c|}
\hline & Www.ijpcs.net \\
\hline & DOI: \\
\hline &
\end{tabular}

\begin{abstract}
Goal: To elucidate the public' experiences and expectations of pharmacists during COVID-19 in Saudi Arabia. Methods: It is three cross-sectional of convenient sampling and calculated number of the subject with power eighty. It was a self-reported electronic survey for the population in the King of Saudi Arabia. It encompassed all citizens who lived in Saudi with the age of more than 18 years and above. The survey entailed of the demographic data patients actual experiences of pharmacists during COVID-19 and patients actual expectations of pharmacists during any other pandemic situation. Survey monkey, Microsoft Excel, and Statistical Package of Social Science (SPSS) were used for the analysis. Results: The total number of responding pharmacists was 461. Of those, 440 (95.44\%) were Saudi, and 344 (74.62\%) were female, with statistical significance between nationality or gender answers $(p<0.001)$. Almost two-thirds of the responders had bachelor's degrees 319 (69.20\%) with statistically noteworthy between among all academic qualifications $(p<0.001)$. Most of the responders were non-healthcare professionals $338(74.45 \%)$, and physicians and nurses representative high percentages 37 (35.92\%) and 31 (30.10\%), respectively, with statistically significant among the remaining answers $(p<0.001)$. The total average scores of patients' actual experiences of pharmacists during COVID-19 were 3.41. The high scores element was pharmacists routinely counsel me regarding the safe and appropriate use of my medications (3.79), and the pharmacist implemented the $\mathrm{MOH}$ covid-19 instructions and guidelines (3.77). The total average scores of patients actual expectations of pharmacists during any other pandemic situation were 3.71 with high scores element was the pharmacist expand their services and will most of my medications request by online and mobile application (3.88) and the pharmacist applied software applications for education for drugs and any pandemic (3.86). Conclusion: The public' experiences and expectations of pharmacist during COVID-19 in Saudi Arabia is very optimistic. Therefore, targeting education, training, declaring the pharmacist's role during pandemic situations, emergency public health emphasizing therapeutic guidelines and preventing drug-related problems is highly proposed for implementations in Saudi Arabia.

Keywords: Public, Experiences, Expectations, Pharmacists, COVID-19, Saudi Arabia.
\end{abstract}

\section{INTRODUCTION}

In the last two years, the biggest pandemic and emergency public heath started worldwide. The viral infectious disease instigated in China and then shifted to all countries. ${ }^{[1]}$ World Health Organization referred numerous warnings about the diseases called Coronavirus or COVID-19. ${ }^{[1]}$ Each government recognized preventive measures before the conditions entrance, followed up the cases, and planned the management for their residents and citizens during the pandemic; the Kingdom of Saudi Arabia did an excellent performance. ${ }^{[2]}$ It stopped all travellers from infected countries from entering. It avoids all inside passengers to travellers outside the county. Besides, also includes keeping distance policy, stopping any activity with crowd people, confirms mask warning in public areas. ${ }^{[2]}$ The government has formulated a national committee to meet this pandemic with higher government administration's total financial and logistic support. ${ }^{[1]}$ The Ministry of Health offers pervasive healthcare activities. They follow-up all-new cases with or without symptoms overseas; the infected are acknowledged to hospitals or critical care services. ${ }^{[2]}$ It planned prevention and treatment protocol of COVID-19 implemented at all the health care services. ${ }^{[2]}$ The $\mathrm{MOH}$ used an electronic system through numerous applications during pandemic situations. Besides, growing the number of beds, opening new hospitals, and organizing the call centre of 937 to receive all healthcare inquiries linked to the pandemic COVID-19. Moreover, the $\mathrm{MOH}$ controlled the clinical trials about COVID-19 management, vaccines organization and delivered free vaccines for all residents and citizens in Saudi Arabia. ${ }^{[1]}$

Various publications discussed pharmacy-related activities in emergency public health time. ${ }^{[3-8]}$ Healthcare professionals achieve all those activities, counting the pharmacy staff, along with the clinical pharmacist or distributive pharmacist, or pharmacy technician. ${ }^{[9]}$ The pharmacist plays a vital role during a pandemic COVID-19. ${ }^{[9-14]}$ The pharmacist delivers home delivery of medications from hospital, community pharmacies and publications about the COVID-19 diseases and 
drug information; ${ }^{[1]}$ also, educational materials by an electronic application and patients education performance. Deliver enough medications, organized disinfectant solution, and hand sanitizer to the patients. ${ }^{[8]}$ Besides, the pharmacists contributed in therapeutic guidelines of the COVID-19 pandemic. $^{[8]}$ The improvement of the pharmacist's activities wants the pharmacist's performance assessment. It needs to discover the patient's experience and future expectations during a pandemic and infectious emergency public health situation. Numerous studies conversed physician or dentist experience and future expectations of pharmacists during regular days. ${ }^{[15-21]}$ Another study talked the perception of pharmacists or drug distribution systems during COVID-19. ${ }^{[22]}$ The authors tried to combine two kinds of tasks by counting patient experience and expectations of the pharmacist and performance during COVID-19: the author is not acquainted with any search about the current topic locally or in Gulf and Middle Eastern countries. The present study purposes to announce the patient experience and expectations of pharmacists during COVID-19 in Saudi Arabia.

\section{METHODS}

It is a two-month cross-sectional study of public' experiences and expectations of pharmacists during COVID-19 in Saudi Arabia. It was a selfreported electronic survey for the population in the King of Saudi Arabia. It encompassed all citizens who lived in Saudi with age more than 18 years and above. Any unfinished reports or locations outside of Saudi Arabia will be omitted from the study. The survey resided of demographic data, counting locations, gender, material status, age, responder qualifications, occupational status, and monthly income. It also includes the second part of patients' actual experiences of pharmacist during COVID-19 and patients actual expectations of pharmacists during any other pandemic situation. The 5-point Likert response scale system was used. The sample was intended according to the previous literature with unlimited population's size, population's percentage $50 \%$, the confidence level $95 \%$ with $\mathrm{z}$ score of 1.96 , margin of error $5 \%$, and drop-out rate $10 \%$. As a result, the sample size will equal 420 or above with a power of study of $80 \% .{ }^{[23-25]}$ The response rate obligatory of calculated sample size at least $60-70 \%$ and above. ${ }^{[25,26]}$ The survey was dispersed through social media and telegram during July and August 2020. The reminder message had been referred every 2-3 weeks. The survey was authenticated through the revision of expert reviewers and pilot testing. Besides, the reliability tests McDonald's $\omega$, Cronbach's $\alpha$, Guttmann's 2, and Guttmann's 6 had been done with the study. The data analysis is finished through the survey monkey system, the Statistical Package of Social Sciences (SPSS), and Jeffery's Amazing Statistics Program (JASP). Besides, it is completed by the Microsoft excel sheet version 16 with description and frequency analysis, good of fitness analysis, correlation analysis, inferential analysis of factors affects pharmacists perceptions of forensic pharmacy. The STROBE (Strengthening the reporting of observational studies in epidemiology statement: guidelines for reporting observational studies) steered the reporting of the current study. ${ }^{[27,28]}$

\section{RESULTS}

The total number of responding pharmacists was 461, with most of them coming from the south area $211(45.77 \%)$, and west area 154 (33.41\%) with statistically noteworthy among the regions $(p<0.001)$. Of those, 440 (95.44\%) were Saudi, and 344 (74.62\%) were female, with statistical consequence between nationality or gender answers $(p<0.001)$. Most of the responders were in age (18-24) years $174(39.19 \%)$ with statistically significant between all ages level $(p<0.001)$. Almost twothirds of the responders had bachelor's degree $319(69.20 \%)$ with statistically significant between among all academic qualifications $(p<0.001)$. Most responders were students $186(40.35 \%)$ and employees 144 (31.24\%), and monthly income less than 3,000 SR was 197 (46.14\%) statistically important between among the remaining answers $(p<0.001)$. Most of the responders were non-healthcare professionals 338 (74.45\%), and physicians and nurses representative high percentages 37 (35.92\%) and 31 (30.10\%), respectively, with statistically significant among the remaining answers $(p<0.001)$. The majority of responders contacted with community pharmacies 282 (62.81\%) or hospital pharmacies 115 (25.61\%) more frequently, while rarely 171 (37.92\%) or sometimes 119 (26.39\%) communicate with pharmacist statistically significant between among the answers $(p<0.001)$. There is a medium positive relationship between Age (years) and monthly income Kendall's tau_b (0.563) or Spearman's rho (0.677) with statistically significant difference $(p>0.05)$ as reconnoitred in Table 1 and 2.

The total average scores of patients' actual experiences of pharmacists during COVID-19 were 3.41. The high scores element was pharmacists routinely direction regarding the safe and fitting use of medications (3.79), the pharmacist executed the $\mathrm{MOH}$ covid-19 instructions and guidelines (3.77), and pharmacists are a reliable source of general drug information (3.74). On the contrary, the lowest score was the pharmacist monitors as a patient response to drug therapy and if a patient encounters any drug-related problem (2.86). In addition, pharmacists routinely notify about less expensive alternatives to the drugs prescribed (3.13), and pharmacists appear willing to take personal responsibility for resolving any drug-related problems they discover with supportive with my doctor (3.14) with statistically significant between answers $(p<0.001)$ as travelled in Table 3.

The total average scores of patients actual expectations of pharmacists during any other pandemic situation were 3.71 with high scores element was the pharmacist expand their services and will most of medications appeal by online and mobile application (3.88). In addition, the pharmacist applied software applications for education for drugs and any pandemic (3.86), and the pharmacist executed the drug therapy guidelines from $\mathrm{MOH}$ (3.81). Besides, the pharmacist can make the essential examination (3.81), and the pharmacist expand the home delivery for medications, medical devices, and instruments free of charge (3.81). On the contrary, the lowest score aspect of nuclear pharmacy was the pharmacist can make the advances examination (3.48), and the pharmacist provide vaccines services for adults and geriatrics (3.4). Besides, the pharmacist in the future had the clinical and administrative privilege as part of pharmacy law (3.64) with statistically noteworthy between answers $(p<0.001)$ as reconnoitred in Table 4 . The reliability test of McDonald's $\omega, 0.942$, Cronbach alpha 0.942, Guttmann's $\lambda 2$, 0.944, and Guttmann's $\lambda 6,0.959$.

Factors persuading the patients' actual experiences or actual expectations of pharmacist. It might affect the patients actual experiences, for instance; location, employment, age (years), nationality, gender, educational level, monthly income, and whether the responders are from healthcare professionals. Using independent samples Kruskal-Wallis test and the Bonferroni correction for multiple tests have adjusted significant values, the results showed as follows. Five locations exaggerated the actual experiences with the highest average score (3.5770) at the south region with statistically significant differences $(\mathrm{p}=0.000)$. The academic qualification and monthly income pretentious the patients actual experiences with statistically significant differences $(p=0.041)$ and $(p=0.000)$, respectively, with nonstatistically significant differences between the academic qualification levels in post hoc analysis $(\mathrm{p}>0.05)$. Other factors (employment, nationality, gender, and does the responders were from healthcare professionals) did not 


\begin{tabular}{|c|c|c|c|}
\hline Nationality & Response Count & Response Percent & $P$ value \\
\hline Central area & 54 & $11.71 \%$ & \multirow[t]{5}{*}{0.000} \\
\hline North area & 13 & $2.82 \%$ & \\
\hline South area & 211 & $45.77 \%$ & \\
\hline East area & 29 & $6.29 \%$ & \\
\hline West area & 154 & $33.41 \%$ & \\
\hline Answered question & 461 & & \\
\hline Skipped question & 0 & & \\
\hline Gender & Response Count & Response Percent & \\
\hline Saudi & 440 & $95.44 \%$ & \multirow[t]{2}{*}{0.000} \\
\hline Non-Saudi & 21 & $4.56 \%$ & \\
\hline Answered question & 461 & & \\
\hline Skipped question & 0 & & \\
\hline Gender & Response Count & Response Percent & \\
\hline Male & 117 & $25.38 \%$ & \multirow{2}{*}{0.000} \\
\hline Female & 344 & $74.62 \%$ & \\
\hline Answered question & 461 & & \\
\hline Skipped question & $\mathbf{0}$ & & \\
\hline Age & Response Count & Response Percent & \\
\hline$<18$ & 19 & $4.28 \%$ & \multirow[t]{8}{*}{0.000} \\
\hline $18-24$ & 174 & $39.19 \%$ & \\
\hline $25-30$ & 68 & $15.32 \%$ & \\
\hline $31-35$ & 29 & $6.53 \%$ & \\
\hline $36-40$ & 34 & $7.66 \%$ & \\
\hline $41-45$ & 32 & $7.21 \%$ & \\
\hline $46-50$ & 27 & $6.08 \%$ & \\
\hline$>50$ & 61 & $13.74 \%$ & \\
\hline Answered question & 444 & & \\
\hline Skipped question & 17 & & \\
\hline
\end{tabular}

affect the patients actual experiences with nonstatistically significant differences $(p>0.05)$. The various factors might impact the patients actual expectations of pharmacists, for instance; location, employment, age (years), nationality, gender, educational level, monthly income, and the responders from healthcare professionals. Five locations affected the Actual Expectations with the highest average score (3.7994) at the south region and west area (3.6340) with statistically significant differences $(p=0.016)$ in post hoc analysis. There were eight levels of age exaggerated the patients actual expectations of pharmacist with highest scores (3.8247) in age (18-14 years) lowest scores (3.4530) in age more 50 years with statistically significant differences $(p=0.001)$ in post hoc analysis. The employment and monthly income exaggerated the patients actual expectations with statistically significant differences $(\mathrm{p}=0.028)$ and $(\mathrm{p}=0.015)$, respectively, with non- statically significant differences in post hoc analysis $(p>0.05)$. Other factors (nationality, gender, academic qualification, and does the responders from healthcare professionals) did not disturb the patients actual experiences with non- statistically significant differences ( $\mathrm{p}>0.05)$, as discovered in Table 5.

The relationship between the patients' actual involvements of pharmacists during COVID-19 and factors includes location, employment, age (years), nationality, gender, educational level, monthly income, and the responders from a healthcare professional. It was verified through a multiple regression model and measured the patients' actual experiences dependent variable and factors viewed as expletory variables. There was a weak relationship $R$ (0.211) with $(p=0.024)$ between the patients actual experiences and factors. There is no positive or negative relationship between patients actual experiences and all factors with non-statistically significant $(\mathrm{p}>0.05)$ through multiple regression model and established by Bootstrap model as explored in Table 7 . The relationship between the patients' actual expectations of pharmacists and factors such as location, employment, age (years), nationality, gender, educational level, monthly income, and the responders from healthcare professionals. It was proved through a multiple regression model and measured the patients actual expectations-dependent factors were observed as the expletory variable. There was a weak relationship $\mathrm{R}(0.217)$ with $(p=0.018)$ between the patients actual expectations and factors. However, there is one factor only; age clarified $16.5 \%$ of the positive relationship of the variation in the patients actual expectations with a statistically significant $(p=0.027)$ through multiple regression model and established by Bootstrap model. The non-existence of multicollinearity verified the relationship among patients actual expectations and one factor with age Variance Inflation Factor (VIF=2.190), which was less than three ${ }^{[29-31]}$ as reconnoitered in Table 8 .

\section{DISCUSSION}

The COVID-19 time was a very grave period locally and internationally. ${ }^{[2]}$ Everything was transformed. Regular working altered to online, typical hospital visiting the online clinic, and traditional distribution from patients visit and get the drugs to medication home delivery. ${ }^{[4,10-14]}$ Various things conflicting the public and change their daily lives and standard behaviour switch to something new in healthcare and pharmacy services. Besides, the hospital or community pharmacist's behaviour reformed from passive to active behaviour with mail or home distribution. As a result, the patients faced new looks from pharmacists during the peak pandemic of the COVID-19 period. ${ }^{[10-13]}$ However, the experiences and expectations of patients from pharmacists are highly requested to know to improve the communication skills between patients and pharmacists, declare the role of pharmacists during pandemic situations and the future expectations of pharmacists toward patients in the coming pandemic cases from the public point of view. The contemporary study was completed by distributing an electronic authenticated and high-reliability survey to a convenient sample with an adequate sample. The author dispersed the study mainly from the south and west regions where authors had lived. The majority of responders were female because of same author's gender. The majority of responders were had a bachelor's degree look like the earlier study ${ }^{[22]}$ with low income that's expected because they were the student and young age 


\begin{tabular}{|c|c|c|c|}
\hline Responder Qualifications & $\begin{array}{c}\text { Response } \\
\text { Count }\end{array}$ & $\begin{array}{c}\text { Response } \\
\text { Percent }\end{array}$ & \\
\hline Doctorate degree & 18 & $3.90 \%$ & \multirow[t]{8}{*}{0.000} \\
\hline Master degree & 30 & $6.51 \%$ & \\
\hline Bachelor Degree & 319 & $69.20 \%$ & \\
\hline Diploma & 25 & $5.42 \%$ & \\
\hline High school & 56 & $12.15 \%$ & \\
\hline Intermediate School & 12 & $2.60 \%$ & \\
\hline Primary School & 0 & $0.00 \%$ & \\
\hline Not educated & 1 & $0.22 \%$ & \\
\hline Answered question & 461 & & \\
\hline Skipped question & $\mathbf{0}$ & & \\
\hline Occupational status & $\begin{array}{c}\text { Response } \\
\text { Count }\end{array}$ & $\begin{array}{c}\text { Response } \\
\text { Percent }\end{array}$ & \\
\hline Employee & 144 & $31.24 \%$ & \multirow[t]{5}{*}{0.000} \\
\hline Unemployed & 70 & $15.18 \%$ & \\
\hline Student & 186 & $40.35 \%$ & \\
\hline Retried & 57 & $12.36 \%$ & \\
\hline Not written & 4 & $0.87 \%$ & \\
\hline Answered question & 461 & & \\
\hline Skipped question & $\mathbf{0}$ & & \\
\hline Monthly income & $\begin{array}{c}\text { Response } \\
\text { Count }\end{array}$ & $\begin{array}{c}\text { Response } \\
\text { Percent }\end{array}$ & \\
\hline$<3,000 \mathrm{SR}$ & 197 & $46.14 \%$ & \multirow[t]{10}{*}{0.000} \\
\hline $3,001-6,000$ & 33 & $7.73 \%$ & \\
\hline $6,001-9,000$ & 33 & $7.73 \%$ & \\
\hline $9,001-12,000$ & 46 & $10.77 \%$ & \\
\hline $12.001-15,000$ & 49 & $11.48 \%$ & \\
\hline $15,001-18,000$ & 25 & $5.85 \%$ & \\
\hline $18,001-21,000$ & 18 & $4.22 \%$ & \\
\hline$>21,000 \mathrm{SR}$ & 26 & $6.09 \%$ & \\
\hline Answered question & 427 & & \\
\hline Skipped question & 34 & & \\
\hline
\end{tabular}

Continued...

\begin{tabular}{|c|c|c|c|}
\hline $\begin{array}{l}\text { Are you a health care } \\
\text { practitioner (Medical } \\
\text { Doctor- Dentist- Pharmacist- } \\
\text { Nurse- Others? }\end{array}$ & $\begin{array}{l}\text { Response } \\
\text { Count }\end{array}$ & $\begin{array}{l}\text { Response } \\
\text { Percent }\end{array}$ & \\
\hline Yes & 116 & $25.55 \%$ & \multirow[t]{2}{*}{0.000} \\
\hline No & 338 & $74.45 \%$ & \\
\hline Answered question & 454 & & \\
\hline Skipped question & 7 & & \\
\hline $\begin{array}{l}\text { If you are a health care } \\
\text { practitioner, you are a }\end{array}$ & $\begin{array}{l}\text { Response } \\
\text { Count }\end{array}$ & $\begin{array}{l}\text { Response } \\
\text { Percent }\end{array}$ & \\
\hline Physician & 37 & $35.92 \%$ & \multirow[t]{4}{*}{0.000} \\
\hline Nurse & 31 & $30.10 \%$ & \\
\hline Nutritionist & 17 & $16.50 \%$ & \\
\hline Pharmacist & 7 & $6.80 \%$ & \\
\hline Laboratory & 4 & $3.88 \%$ & \\
\hline Radiology & 2 & $1.94 \%$ & \\
\hline Physiotherapy & 3 & $2.91 \%$ & \\
\hline Other (please specify) & 2 & $1.94 \%$ & \\
\hline Answered question & 103 & & \\
\hline Skipped question & 358 & & \\
\hline $\begin{array}{l}\text { Which type of pharmacies } \\
\text { are you more frequent } \\
\text { communication }\end{array}$ & $\begin{array}{l}\text { Response } \\
\text { Count }\end{array}$ & $\begin{array}{l}\text { Response } \\
\text { Percent }\end{array}$ & \\
\hline Hospital pharmacy & 115 & $25.61 \%$ & \\
\hline Community pharmacies & 282 & $62.81 \%$ & \\
\hline Primary healthcare pharmacy & 60 & $13.36 \%$ & \\
\hline Private hospital pharmacies & 38 & $8.46 \%$ & \\
\hline Non & 12 & $2.67 \%$ & \\
\hline Answered question & 449 & & \\
\hline Skipped question & 12 & & \\
\hline $\begin{array}{l}\text { How do you frequently } \\
\text { communicate with the } \\
\text { pharmacist? }\end{array}$ & $\begin{array}{l}\text { Response } \\
\text { Count }\end{array}$ & $\begin{array}{l}\text { Response } \\
\text { Percent }\end{array}$ & \\
\hline Always & 31 & $6.87 \%$ & \multirow[t]{5}{*}{0.000} \\
\hline Most of the time & 54 & $11.97 \%$ & \\
\hline Sometimes & 119 & $26.39 \%$ & \\
\hline Rarely & 171 & $37.92 \%$ & \\
\hline Never & 76 & $16.85 \%$ & \\
\hline Answered question & 451 & & \\
\hline Skipped question & 10 & & \\
\hline
\end{tabular}

recently graduated. The study targets were nonhealthcare professionals. However, one-quarter had responded from healthcare professionals. Therefore, it was a good opportunity to know their experiences and expectations of pharmacists. The existing results exposed that most patients communicated with community pharmacies. It has been expected to be more reachable to them and safer than the hospital in COVID-19 visiting cases. However, the contact situation was rarely or sometimes. It has echoed that the patients do not need any medications from community pharmacies, get their medicines from the hospital, or receive their medications through home delivery. However, patients did not contact a pharmacist during or after delivery.

The patients had positive experiences with pharmacists during COVID-19 with high experiences with patient's medications education or relating the MOH COVID-19 regulation and reflect the pharmacist as sources of drug information resemble earlier study. ${ }^{[22]}$ The patient analysis through community pharmacy is well known of the prior literature and might upsurge during COVID 19 due to the demand of receive counselling with new pandemic situations. . $^{[4,10-14,32-36]}$ The pharmacist displayed positive cooperation with $\mathrm{MOH}$ regularly, which was exceptional to prevent any further distribution of pandemic disease. The pharmacist experiences as the sources of drug information for patients, which was part of their active role in society during pandemic situations. However, the patients had negative experiences with numerous activities during 


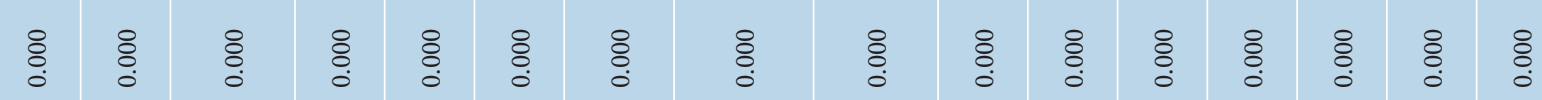

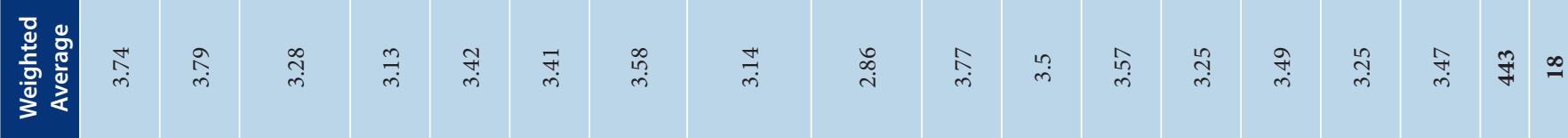

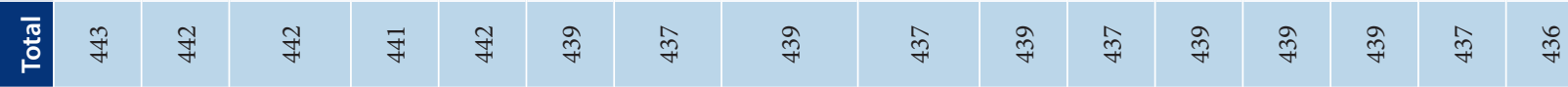

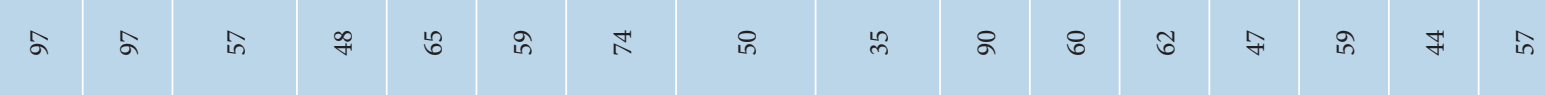

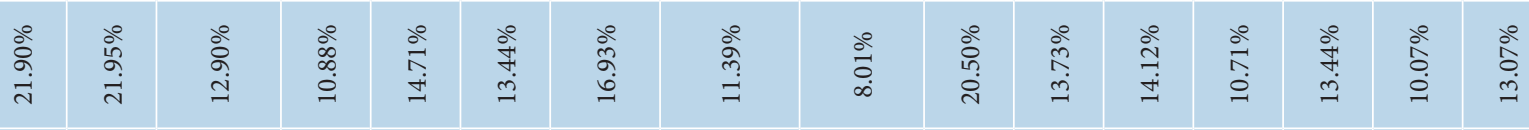

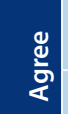

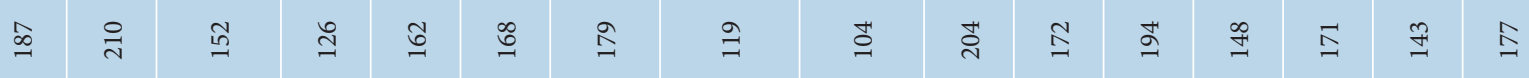

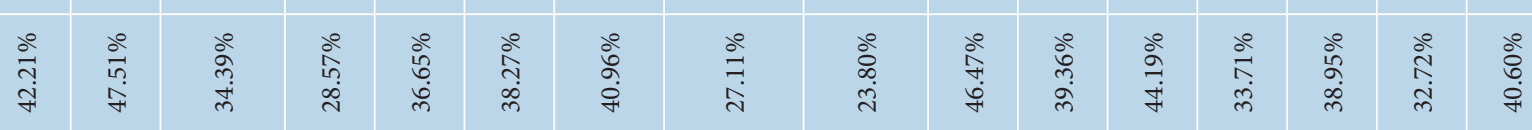

高

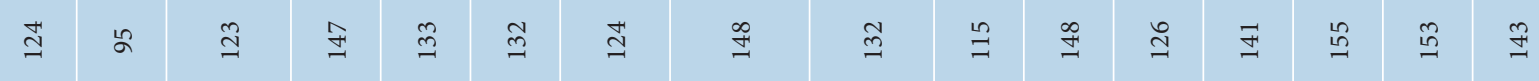

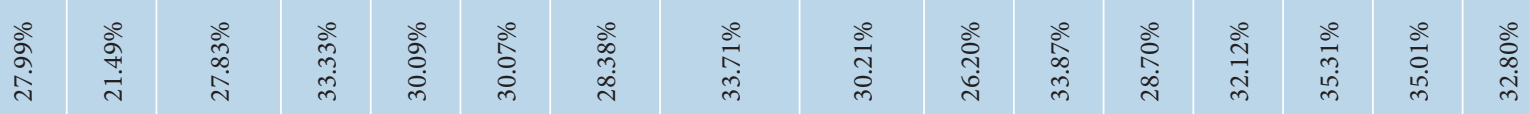

$\stackrel{\infty}{\rightarrow} \stackrel{\infty}{\wedge}$ in

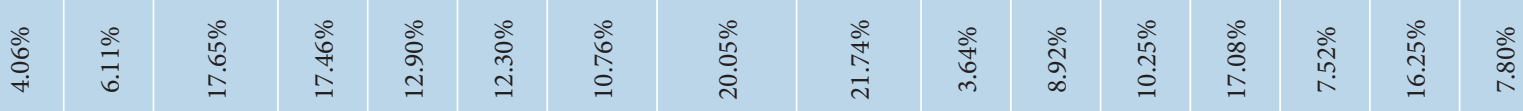

官

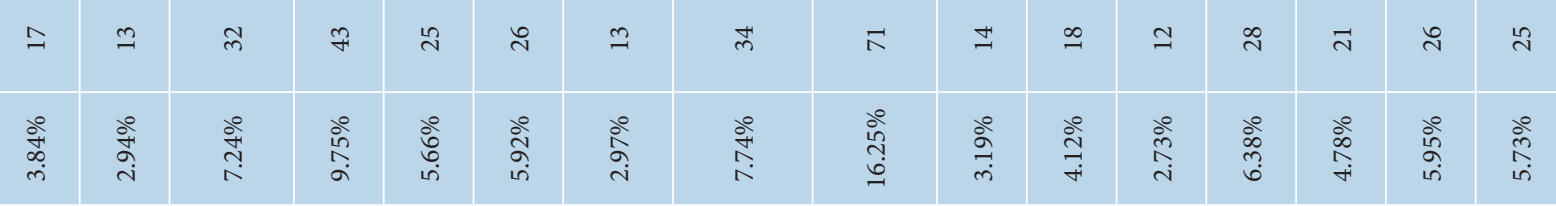




\begin{tabular}{|c|c|c|c|c|c|c|c|c|c|c|c|c|c|}
\hline \multirow{2}{*}{$\begin{array}{l}\text { The pharmacist in the } \\
\text { future had the clinical and } \\
\text { administrative privilege as } \\
\text { part of pharmacy law }\end{array}$} & \multicolumn{2}{|c|}{$\begin{array}{l}\text { Strongly } \\
\text { Disagree }\end{array}$} & \multicolumn{2}{|c|}{ Disagree } & \multicolumn{2}{|c|}{ Neutral } & \multicolumn{2}{|c|}{ Agree } & \multicolumn{2}{|c|}{ Strongly agree } & \multirow{2}{*}{$\begin{array}{l}\text { Total } \\
436\end{array}$} & \multirow{2}{*}{$\begin{array}{c}\text { Weighted } \\
\text { Average } \\
\\
3.64\end{array}$} & \multirow[b]{2}{*}{0.000} \\
\hline & $2.98 \%$ & 13 & $7.57 \%$ & 33 & $27.52 \%$ & 120 & $45.87 \%$ & 200 & $16.06 \%$ & 70 & & & \\
\hline $\begin{array}{l}\text { In the future, the pharmacist } \\
\text { open to me, especially } \\
\text { medications profile to follow } \\
\text { up my medications }\end{array}$ & $3.44 \%$ & 15 & $5.96 \%$ & 26 & $22.71 \%$ & 99 & $49.77 \%$ & 217 & $18.12 \%$ & 79 & 436 & 3.73 & 0.000 \\
\hline $\begin{array}{l}\text { The pharmacist document } \\
\text { any drug related problems in } \\
\text { the pharmacy patients profile }\end{array}$ & $3.22 \%$ & 14 & $6.44 \%$ & 28 & $24.37 \%$ & 106 & $47.82 \%$ & 208 & $18.16 \%$ & 79 & 435 & 3.71 & 0.000 \\
\hline $\begin{array}{l}\text { In the future, the pharmacist } \\
\text { provide vaccines services for } \\
\text { adults and geriatrics }\end{array}$ & $6.42 \%$ & 28 & $11.70 \%$ & 51 & $25.92 \%$ & 113 & $38.30 \%$ & 167 & $17.66 \%$ & 77 & 436 & 3.49 & 0.000 \\
\hline $\begin{array}{l}\text { The pharmacist implemented } \\
\text { the drug therapy guidelines } \\
\text { from } \mathrm{MOH}\end{array}$ & $1.83 \%$ & 8 & $5.73 \%$ & 25 & $22.94 \%$ & 100 & $48.85 \%$ & 213 & $20.64 \%$ & 90 & 436 & 3.81 & 0.000 \\
\hline $\begin{array}{l}\text { The pharmacist follow my } \\
\text { situation and medications } \\
\text { trough software application }\end{array}$ & $2.52 \%$ & 11 & $8.03 \%$ & 35 & $26.15 \%$ & 114 & $46.33 \%$ & 202 & $16.97 \%$ & 74 & 436 & 3.67 & 0.000 \\
\hline $\begin{array}{l}\text { In the future, the pharmacist } \\
\text { can make the essential } \\
\text { examination }\end{array}$ & $2.08 \%$ & 9 & $6.24 \%$ & 27 & $22.63 \%$ & 98 & $46.42 \%$ & 201 & $22.63 \%$ & 98 & 433 & 3.81 & 0.000 \\
\hline $\begin{array}{l}\text { In the future, the } \\
\text { pharmacist can make the } \\
\text { advances examination } \\
\text { (LDL,HDL,TG,INR) }\end{array}$ & $4.36 \%$ & 19 & $12.61 \%$ & 55 & $29.59 \%$ & 129 & $37.61 \%$ & 164 & $15.83 \%$ & 69 & 436 & 3.48 & 0.000 \\
\hline $\begin{array}{l}\text { The pharmacist used } \\
\text { software applications for } \\
\text { education for medications } \\
\text { and any pandemic situations }\end{array}$ & $1.83 \%$ & 8 & $5.03 \%$ & 22 & $20.37 \%$ & 89 & $51.03 \%$ & 223 & $21.74 \%$ & 95 & 437 & 3.86 & 0.000 \\
\hline $\begin{array}{l}\text { The pharmacist expand } \\
\text { their services and will most } \\
\text { of my medications request } \\
\text { by online and mobile } \\
\text { application }\end{array}$ & $1.14 \%$ & 5 & $4.12 \%$ & 18 & $21.28 \%$ & 93 & $52.63 \%$ & 230 & $20.82 \%$ & 91 & 437 & 3.88 & 0.000 \\
\hline $\begin{array}{l}\text { In the future, the pharmacist } \\
\text { expand the home delivery } \\
\text { for my medications, medical } \\
\text { devices and instruments free } \\
\text { of charge }\end{array}$ & $2.97 \%$ & 13 & $7.78 \%$ & 34 & $18.31 \%$ & 80 & $47.60 \%$ & 208 & $23.34 \%$ & 102 & 437 & 3.81 & 0.000 \\
\hline Answered & & & & & & & & & & & & 439 & \\
\hline Skipped & & & & & & & & & & & & 22 & \\
\hline
\end{tabular}

pandemic COVID-19 like monitoring drug therapy response that might be linked to insufficient or unviable documentation of medications history, or there was no linking with patient's medications hospital records. The new system of Wasfaty will resolve this problem in the future. Wasfaty is the latest method of community pharmacist distribution medications on behalf of hospital pharmacies from governmental healthcare sectors. ${ }^{[36,37]}$

Besides, the Wasfaty can solve the other problem of preventing adverse drug reactions and picking the best price for patients.
Currently, there are support teams accountable for community pharmacists discussing with physicians or pharmacists any interventions or medication errors. Additionally, the implementation of health insurance might aid the pharmacist set up therapeutic guidelines and a strategic monitoring system of drug therapy.

In the study results, the patients likely several activities from pharmacists in the future. First, the patients wish to enlarge the online requesting of medications by using mobile applications or internet websites. Second, they would like to set up therapeutic guidelines from $\mathrm{MOH}$, which is very supportive in the cost-effective treatment and declining drugrelated problems. Third, the patient's wish from pharmacists to deliver vital examinations like checking blood sugar or blood pressure, or cholesterol level, which the $\mathrm{MOH}$ allows to deliver by the community pharmacist. Recently, the $\mathrm{MOH}$ permits the pharmacist to implement a vaccination program emphasizing COVID19 vaccines look like the clinical pharmacist role in European countries. ${ }^{[13]}$ The patients are less likely to make advance examinations 


\begin{tabular}{|c|c|c|c|c|c|c|c|c|c|c|c|c|c|c|c|}
\hline & & & & Patient: & Actual Ex & perience & & & & Patie & nts Actua & I Expect & ions of $\mathrm{r}$ & armacist & \\
\hline & Factors & $\mathbf{N}$ & $\begin{array}{l}\text { Average } \\
\text { scores }\end{array}$ & Std. D & Median & $\begin{array}{l}\text { Lower } \\
\text { Bound }\end{array}$ & $\begin{array}{l}\text { Upper } \\
\text { Bound }\end{array}$ & $P$-value & $\mathbf{N}$ & $\begin{array}{l}\text { Average } \\
\text { scores }\end{array}$ & Std. D & Median & $\begin{array}{l}\text { Lower } \\
\text { Bound }\end{array}$ & $\begin{array}{l}\text { Upper } \\
\text { Bound }\end{array}$ & $P$-value \\
\hline \multirow{6}{*}{ 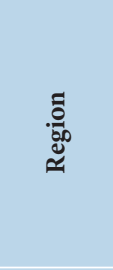 } & Central & 48 & 3.3602 & .75378 & 3.3438 & 3.1413 & 3.5790 & \multirow{5}{*}{0.000} & 48 & 3.7519 & .64385 & 3.7727 & 3.5649 & 3.9388 & \multirow{5}{*}{0.016} \\
\hline & North & 12 & 3.1458 & .56113 & 3.1563 & 2.7893 & 3.5024 & & 12 & 3.3939 & .84068 & 3.3636 & 2.8598 & 3.9281 & \\
\hline & South & 173 & $3.5770^{*}$ & .80321 & 3.6250 & 3.4564 & 3.6975 & & 173 & $3.7994^{*}$ & .77612 & 4.0000 & 3.6829 & 3.9158 & \\
\hline & East & 25 & 3.2035 & .68023 & 3.1250 & 2.9227 & 3.4843 & & 25 & 3.6349 & .68639 & 3.7273 & 3.3516 & 3.9182 & \\
\hline & West & 129 & 3.2969 & .57599 & 3.2500 & 3.1966 & 3.3972 & & 129 & $3.6340^{*}$ & .60906 & 3.7273 & 3.5279 & 3.7401 & \\
\hline & Total & 387 & & & & & & & 387 & & & & & & \\
\hline \multirow{6}{*}{ 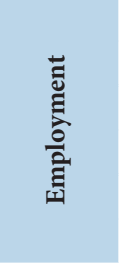 } & Employee & 136 & 3.4113 & .68850 & 3.3750 & 3.2946 & 3.5281 & \multirow{5}{*}{0.103} & 135 & 3.7742 & .64292 & 3.8182 & 3.6647 & 3.8836 & \multirow{5}{*}{0.041} \\
\hline & Unemployed & 68 & 3.4480 & .79668 & 3.3875 & 3.2551 & 3.6408 & & 68 & 3.8176 & .77306 & 4.0000 & 3.6305 & 4.0048 & \\
\hline & Student & 174 & 3.4738 & .67030 & 3.4375 & 3.3735 & 3.5741 & & 171 & 3.6999 & .67255 & 3.8182 & 3.5984 & 3.8015 & \\
\hline & Retried & 57 & 3.2930 & .75892 & 3.2500 & 3.0916 & 3.4944 & & 57 & 3.5946 & .71094 & 3.6000 & 3.4059 & 3.7832 & \\
\hline & Not written & 4 & 2.4219 & 1.00568 & 2.3750 & .8216 & 4.0221 & & 4 & 2.5000 & 1.22980 & 2.5909 & .5431 & 4.4569 & \\
\hline & Total & 439 & & & & & & & 435 & & & & & & \\
\hline \multirow{9}{*}{ 蕰 } & $<18$ & 18 & 3.6694 & .62624 & 3.5625 & 3.3580 & 3.9809 & 0.068 & 18 & 3.8182 & .84414 & 3.9091 & 3.4113 & 4.2250 & 0.001 \\
\hline & $18-24$ & 147 & 3.5152 & .74902 & 3.5000 & 3.3932 & 3.6373 & & 147 & $3.8247^{*}$ & .69099 & 3.9545 & 3.7182 & 3.9313 & \\
\hline & $25-30$ & 56 & 3.3650 & .74006 & 3.2500 & 3.1668 & 3.5631 & & 56 & 3.8254 & .65579 & 3.9091 & 3.6588 & 3.9919 & \\
\hline & $31-35$ & 26 & 3.3819 & .71906 & 3.3875 & 3.0915 & 3.6723 & & 26 & 3.7806 & .53591 & 3.9091 & 3.5767 & 3.9844 & \\
\hline & $36-40$ & 29 & 3.4914 & .78822 & 3.6250 & 3.1916 & 3.7912 & & 29 & 3.8892 & .59220 & 3.9091 & 3.6757 & 4.1027 & \\
\hline & $41-45$ & 29 & 3.3125 & .56026 & 3.3750 & 3.0994 & 3.5256 & & 29 & 3.5220 & .73742 & 3.6364 & 3.2515 & 3.7925 & \\
\hline & $46-50$ & 25 & 3.1658 & .64036 & 3.2500 & 2.9015 & 3.4302 & & 25 & 3.4471 & .77547 & 3.2727 & 3.1404 & 3.7539 & \\
\hline & $>50$ & 57 & 3.2917 & .72967 & 3.1250 & 3.0981 & 3.4853 & & 57 & $3.4530^{*}$ & .69981 & 3.5455 & 3.2706 & 3.6354 & \\
\hline & Total & 387 & & & & & & & 387 & & & & & & \\
\hline \multirow{3}{*}{ 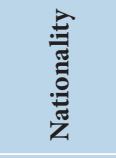 } & Saudi & 367 & 3.4152 & .72937 & 3.3750 & 3.3403 & 3.4900 & \multirow{2}{*}{0.548} & 367 & 3.7103 & .70899 & 3.8182 & 3.6375 & 3.7831 & \multirow{2}{*}{0.600} \\
\hline & Non-Saudi & 20 & 3.4938 & .66265 & 3.4375 & 3.1836 & 3.8039 & & 20 & 3.8045 & .69000 & 3.8636 & 3.4816 & 4.1275 & \\
\hline & Total & 387 & & & & & & & 387 & & & & & & \\
\hline \multirow{3}{*}{ تूँ } & Male & 100 & 3.2678 & .76687 & 3.2500 & 3.1156 & 3.4199 & \multirow{2}{*}{0.063} & 100 & 3.6034 & .77623 & 3.8182 & 3.4493 & 3.7574 & \multirow{2}{*}{0.222} \\
\hline & Female & 287 & 3.4720 & .70426 & 3.3750 & 3.3902 & 3.5538 & & 287 & 3.7541 & .67899 & 3.8182 & 3.6752 & 3.8330 & \\
\hline & Total & 387 & & & & & & & 387 & & & & & & \\
\hline \multirow{7}{*}{ 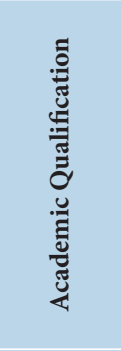 } & Doctorate & 18 & 3.1771 & .63675 & 3.0313 & 2.8604 & 3.4937 & \multirow{6}{*}{0.0} & 18 & 3.4838 & .64591 & 3.4545 & 3.1626 & 3.8050 & \multirow{6}{*}{0.289} \\
\hline & Master & 27 & 3.1667 & .64067 & 3.2500 & 2.9132 & 3.4201 & & 27 & 3.5354 & .70793 & 3.6364 & 3.2553 & 3.8154 & \\
\hline & Bachelor & 271 & 3.4174 & .72172 & 3.3750 & 3.3311 & 3.5037 & & 271 & 3.7285 & .70706 & 3.8182 & 3.6440 & 3.8131 & \\
\hline & Diploma & 20 & 3.6675 & .76945 & 3.8438 & 3.3074 & 4.0276 & & 20 & 3.7182 & .69165 & 3.8636 & 3.3945 & 4.0419 & \\
\hline & High school & 43 & 3.5500 & .78165 & 3.3750 & 3.3094 & 3.7906 & & 43 & 3.8349 & .72816 & 4.0000 & 3.6108 & 4.0590 & \\
\hline & $\begin{array}{l}\text { Intermediate } \\
\text { School }\end{array}$ & 8 & 3.5547 & .67185 & 3.2813 & 2.9930 & 4.1164 & & 8 & 3.7386 & .77663 & 3.6818 & 3.0894 & 4.3879 & \\
\hline & Total & 387 & & & & & & & 387 & & & & & & \\
\hline \multirow{9}{*}{ 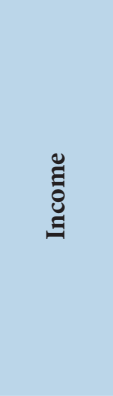 } & $<3,000 \mathrm{SR}$ & 179 & 3.5262 & .73539 & 3.5000 & 3.4178 & 3.6347 & & 179 & 3.8465 & .69236 & 4.0000 & 3.7444 & 3.9486 & \\
\hline & $3,001-6,000$ & 29 & 3.3211 & .60682 & 3.2500 & 3.0903 & 3.5519 & & 29 & 3.5799 & .62580 & 3.7273 & 3.3419 & 3.8180 & \\
\hline & $6,001-9,000$ & 29 & 3.4103 & .70443 & 3.3125 & 3.1424 & 3.6783 & & 29 & 3.5442 & .61402 & 3.6364 & 3.3106 & 3.7778 & \\
\hline & $9,001-12,000$ & 42 & 3.4003 & .71515 & 3.4063 & 3.1774 & 3.6232 & 0015 & 42 & 3.5742 & .66083 & 3.7273 & 3.3683 & 3.7802 & 0 \\
\hline & $12.001-15,000$ & 44 & 3.4067 & .81044 & 3.4063 & 3.1603 & 3.6531 & 8.015 & 44 & 3.8860 & .74685 & 3.8636 & 3.6589 & 4.1130 & \\
\hline & $15,001-18,000$ & 22 & 3.1989 & .69078 & 3.1875 & 2.8926 & 3.5051 & & 22 & 3.5992 & .65053 & 3.6364 & 3.3107 & 3.8876 & \\
\hline & $18,001-21,000$ & 17 & 3.0515 & .69850 & 2.8750 & 2.6923 & 3.4106 & & 17 & 3.4599 & .78102 & 3.7273 & 3.0583 & 3.8615 & \\
\hline & $>21,000 \mathrm{SR}$ & 25 & 3.2750 & .62656 & 3.0625 & 3.0164 & 3.5336 & & 25 & $3.3418^{*}$ & .77285 & 3.4545 & 3.0228 & 3.6608 & \\
\hline & Total & 387 & & & & & & & 387 & & & & & & \\
\hline & Yes & 106 & 3.4474 & .77618 & 3.5000 & 3.2979 & 3.5969 & 0.402 & 106 & 3.7035 & .75187 & 3.8636 & 3.5587 & 3.8483 & 0.799 \\
\hline 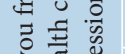 & No & 281 & 3.4086 & .70658 & 3.3125 & 3.3256 & 3.4916 & & 281 & 3.7196 & .69131 & 3.8182 & 3.6384 & 3.8008 & \\
\hline 运 气 & Total & 387 & & & & & & & 387 & & & & & & \\
\hline
\end{tabular}




\begin{tabular}{|c|c|c|c|c|c|c|c|c|c|c|c|c|c|c|}
\hline & \multirow[b]{2}{*}{ Model } & \multirow[b]{2}{*}{$\mathbf{R}$} & \multirow[b]{2}{*}{ R Square } & \multirow[b]{2}{*}{$\mathbf{F}$} & \multirow[b]{2}{*}{ Sig. } & \multicolumn{2}{|c|}{$\begin{array}{l}\text { Unstandardized } \\
\text { Coefficients }\end{array}$} & \multirow{2}{*}{\begin{tabular}{|c} 
Standardized \\
Coefficients \\
Beta \\
\end{tabular}} & \multirow[b]{2}{*}{$\mathbf{t}$} & \multirow[b]{2}{*}{ Sig. } & \multicolumn{2}{|c|}{$\begin{array}{l}95.0 \% \text { Confidence } \\
\text { Interval for B }\end{array}$} & \multicolumn{2}{|c|}{$\begin{array}{l}\text { Collinearity } \\
\text { Statistics }\end{array}$} \\
\hline & & & & & & B & $\begin{array}{l}\text { Std. } \\
\text { Error }\end{array}$ & & & & $\begin{array}{l}\text { Lower } \\
\text { Bound }\end{array}$ & $\begin{array}{l}\text { Upper } \\
\text { Bound }\end{array}$ & Tolerance & VIF \\
\hline \multirow[t]{9}{*}{1} & (Constant) & $.211^{\mathrm{b}}$ & .045 & 2.236 & $.024^{\mathrm{b}}$ & 2.988 & 0.333 & & 8.986 & 0.000 & 2.334 & 3.642 & & \\
\hline & Location & & & & & -0.027 & 0.030 & -0.049 & -0.912 & 0.362 & -0.086 & 0.031 & 0.861 & 1.162 \\
\hline & Site of work & & & & & 0.017 & 0.035 & 0.026 & 0.482 & 0.630 & -0.052 & 0.085 & 0.848 & 1.179 \\
\hline & Age (years) & & & & & -0.020 & 0.023 & -0.064 & -0.859 & 0.391 & -0.065 & 0.026 & 0.454 & 2.202 \\
\hline & Nationality & & & & & 0.066 & 0.169 & 0.020 & 0.389 & 0.697 & -0.266 & 0.398 & 0.944 & 1.059 \\
\hline & Gender & & & & & 0.163 & 0.086 & 0.099 & 1.884 & 0.060 & -0.007 & 0.333 & 0.898 & 1.114 \\
\hline & Educational level & & & & & 0.071 & 0.042 & 0.093 & 1.673 & 0.095 & -0.012 & 0.154 & 0.801 & 1.248 \\
\hline & Monthly income & & & & & -0.011 & 0.023 & -0.035 & -0.485 & 0.628 & -0.056 & 0.034 & 0.468 & 2.137 \\
\hline & $\begin{array}{l}\text { Are you from } \\
\text { a health care } \\
\text { professional }\end{array}$ & & & & & 0.014 & 0.086 & 0.009 & 0.165 & 0.869 & -0.156 & 0.184 & 0.874 & 1.144 \\
\hline
\end{tabular}

a. Dependent Variable: Patients Actual Experiences, Predictors: (Constant), Location, Site of work, Age, Nationality, Gender, Educational level, Monthly income, Are you from the health care professional (Medical Doctor- Dentist- Pharmacist- Nurse- Others),

\begin{tabular}{|c|c|c|c|c|c|c|c|}
\hline \multicolumn{8}{|c|}{ Bootstrap for Coefficients } \\
\hline & \multirow[b]{3}{*}{ Model } & \multirow[b]{3}{*}{ B } & \multicolumn{5}{|c|}{ Bootstrap $^{a}$} \\
\hline & & & \multirow[b]{2}{*}{ Bias } & \multirow[b]{2}{*}{ Std. Error } & \multirow[b]{2}{*}{ Sig. (2-tailed) } & \multicolumn{2}{|c|}{$\mathbf{9 5} \%$ Confidence Interval } \\
\hline & & & & & & Lower & Upper \\
\hline \multirow[t]{9}{*}{1} & (Constant) & 2.988 & -0.025 & 0.333 & 0.001 & 2.290 & 3.607 \\
\hline & Location & -0.027 & 0.002 & 0.031 & 0.356 & -0.084 & 0.035 \\
\hline & Site of work & 0.017 & 0.000 & 0.036 & 0.630 & -0.054 & 0.088 \\
\hline & Age (years) & -0.020 & -0.002 & 0.024 & 0.396 & -0.069 & 0.025 \\
\hline & Nationality & 0.066 & 0.007 & 0.163 & 0.677 & -0.249 & 0.407 \\
\hline & Gender & 0.163 & 0.001 & 0.089 & 0.075 & -0.014 & 0.344 \\
\hline & Educational level & 0.071 & 0.001 & 0.043 & 0.099 & -0.014 & 0.160 \\
\hline & Monthly income & -0.011 & 0.001 & 0.023 & 0.627 & -0.054 & 0.036 \\
\hline & Are you from a health care professional & 0.014 & 0.007 & 0.094 & 0.867 & -0.168 & 0.202 \\
\hline
\end{tabular}

a. Unless otherwise noted, bootstrap results are based on 1000 bootstrap samples

or prescribe medications, and this is normal because the patients think that's physicians' job or might need numerous equipment to resemble earlier studies. ${ }^{[22]}$ The patients might be fried to let the pharmacist provide vaccines or prescribe medications not regularly found in local or Gulf countries. ${ }^{[13,38-41]}$ Further, public information and education with the new job of pharmacists can deliver through community pharmacy is recommended in Saudi Arabia.

Numerous factors might touch the patient's experiences or expectations of pharmacists during pandemic situations COVID-19. Factors comprise location, employment, age, nationality, gender, academic qualifications, monthly income, and public or healthcare. There are no factors with non-statistically significant differences moving the patient's experiences or expectations of pharmacists during pandemic situations COVID-19.
There is not any difference between public or healthcare professionals. The only south region had more positive involvements and expectations of pharmacists without a known reason. Moreover, age factor with age (18-24 years) had more positive expectations of pharmacists than others might relate more communication and ask drug information to the pharmacists.

The patient's experiences during pandemic COVID-19 was decent and more implementation of new community pharmacy are highly suggested in the Kingdom of Saudi Arabia.

\section{Limitations}

Although informatics as information had been discovered from the existing study, various limitations encompassed the responder's unequal distribution in the locations, employment, age, gender, academic qualifications, monthly income, the age levels came from female and a young age with student qualifications. Further studies are mandatory with equal distribution of preceding elements.

\section{CONCLUSION}

The public's experiences and expectations of pharmacists during COVID-19 were positive. There were no differences between public or healthcare providers in the awareness between pharmacists' experiences and expectations. There are no factors that mark the responder's patient's experiences and the pharmacist expectations. More pharmacist involvement through setting therapeutic guidelines and close monitoring of drug-related problems during the pandemic situation is obligatory in the future. 


\begin{tabular}{|c|c|c|c|c|c|c|c|c|c|c|c|c|c|c|}
\hline & \multirow[b]{2}{*}{ Model } & \multirow[b]{2}{*}{$\mathbf{R}$} & \multirow[b]{2}{*}{ R Square } & \multirow[b]{2}{*}{$\mathbf{F}$} & \multirow[b]{2}{*}{ Sig. } & \multicolumn{2}{|c|}{$\begin{array}{l}\text { Unstandardized } \\
\text { Coefficients }\end{array}$} & \multirow{2}{*}{$\begin{array}{c}\begin{array}{c}\text { Standardized } \\
\text { Coefficients }\end{array} \\
\text { Beta }\end{array}$} & \multirow[b]{2}{*}{$t$} & \multirow[b]{2}{*}{ Sig. } & \multicolumn{2}{|c|}{$\begin{array}{l}95.0 \% \text { Confidence } \\
\text { Interval for B }\end{array}$} & \multicolumn{2}{|c|}{$\begin{array}{l}\text { Collinearity } \\
\text { Statistics }\end{array}$} \\
\hline & & & & & & B & $\begin{array}{l}\text { Std. } \\
\text { Error }\end{array}$ & & & & $\begin{array}{l}\text { Lower } \\
\text { Bound }\end{array}$ & $\begin{array}{l}\text { Upper } \\
\text { Bound }\end{array}$ & Tolerance & VIF \\
\hline \multirow[t]{9}{*}{1} & (Constant) & $.217^{\mathrm{b}}$ & 0.047 & 2.349 & $.018^{\mathrm{b}}$ & 3.460 & 0.324 & & 10.668 & 0.000 & 2.823 & 4.098 & & \\
\hline & Location & & & & & -0.006 & 0.029 & -0.011 & -0.195 & 0.845 & -0.063 & 0.051 & 0.862 & 1.160 \\
\hline & Site of work & & & & & -0.004 & 0.034 & -0.006 & -0.113 & 0.910 & -0.071 & 0.063 & 0.849 & 1.178 \\
\hline & Age (years) & & & & & -0.050 & 0.023 & -0.165 & -2.223 & 0.027 & -0.094 & -0.006 & 0.457 & 2.190 \\
\hline & Nationality & & & & & 0.104 & 0.165 & 0.033 & 0.631 & 0.529 & -0.220 & 0.427 & 0.943 & 1.060 \\
\hline & Gender & & & & & 0.111 & 0.085 & 0.069 & 1.304 & 0.193 & -0.056 & 0.277 & 0.901 & 1.109 \\
\hline & Educational level & & & & & 0.016 & 0.041 & 0.022 & 0.390 & 0.697 & -0.065 & 0.097 & 0.803 & 1.246 \\
\hline & Monthly income & & & & & -0.011 & 0.022 & -0.036 & -0.498 & 0.619 & -0.055 & 0.033 & 0.470 & 2.128 \\
\hline & $\begin{array}{l}\text { Are you from } \\
\text { a health care } \\
\text { professional }\end{array}$ & & & & & 0.094 & 0.085 & 0.060 & 1.118 & 0.264 & -0.072 & 0.261 & 0.875 & 1.143 \\
\hline
\end{tabular}

a. Dependent Variable: Patients Actual Expectations of pharmacist, Predictors: (Constant), Location, Site of work, Age, Nationality, Gender, Educational level, Monthly income, Are you from the health care professional (Medical Doctor- Dentist- Pharmacist- Nurse- Others),

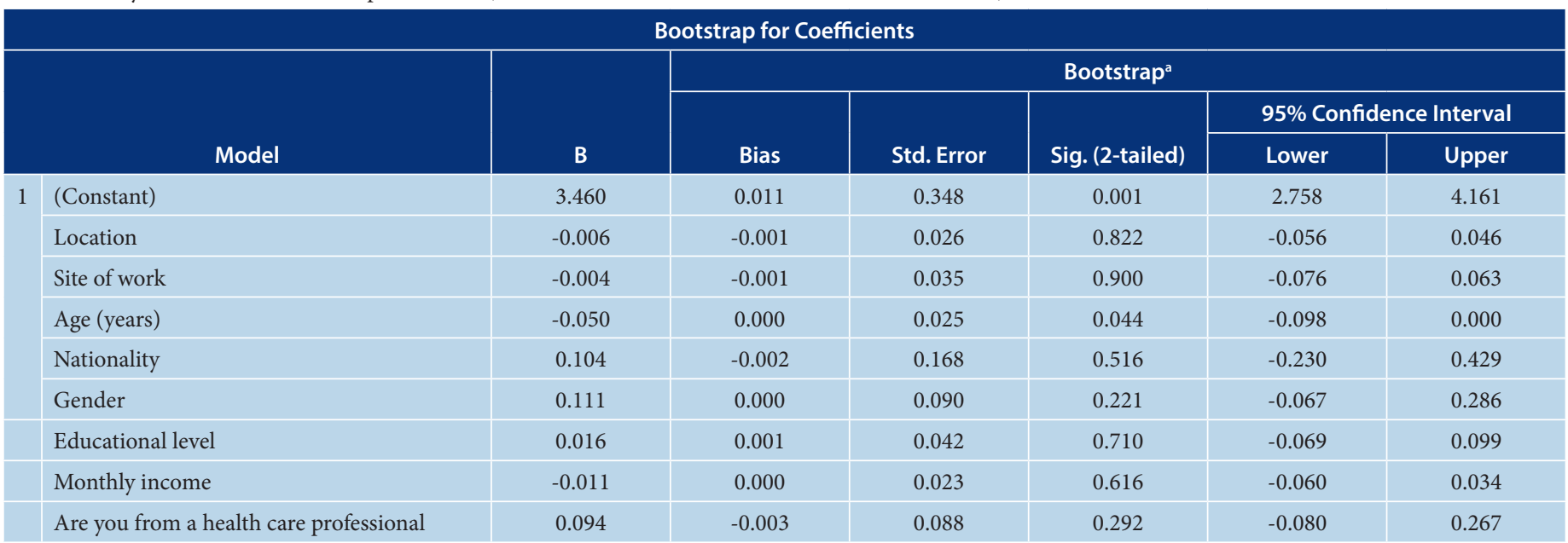

a. Unless otherwise noted, bootstrap results are based on 1000 bootstrap samples

\section{ACKNOWLEDGEMENT}

None.

\section{CONFLICT OF INTEREST}

The Authors declare that there is no Conflict of Interest

\section{Funding}

None

\section{Consent for Publications}

Informed consent was obtained from all the participants

\section{Ethical Approval}

This research was exempted from research and ethical committee or an institutional review board (IRB) approval. https://www.hhs.gov/ohrp/regulations-andpolicy/decision-charts-2018/index.html

\section{ABBREVIATIONS}

MOH: Ministry of Health; KSA: Kingdom of Saudi Arabia; COVID-19: Coronavirus; SPSS: Statistical Package of Social Sciences; JASP: Jeffery's Amazing Statistics Program; Strobe: Strengthening the reporting of observational studies in epidemiology statement: guidelines for reporting observational studies; SFDA: Saudi Food and Drug Authority; CBAHI: Saudi Central Board for Accreditation of Healthcare Institutions.

\section{ORCID ID}

Yousef Ahmed Alomi org/0000-0003-1381-628X

\section{REFERENCES}

1. Ahmad A, Alkharfy KM, Alrabiah Z, Alhossan A Saudi Arabia, pharmacists and COVID-19 pandemic J Pharm Policy Pract. 2020;13(1):41. doi: 10.1186/ s40545-020-00243-1, PMID 32670595.

2. Algaissi AA, Alharbi NK, Hassanain M, Hashem AM Preparedness and response to COVID-19 in Saud Arabia: building on MERS experience. J Infect Public Health. 2020;13(6):834-8. doi: 10.1016/j. jiph.2020.04.016, PMID 32451260.

3. Badreldin HA, Raslan $\mathrm{S}$, Almudaiheem $\mathrm{H}_{\text {, }}$ Alomari B, Almowaina S, Joharji $\mathrm{H}$, et al. Pharmacists roles and responsibilities during epidemics and pandemics in Saudi Arabia: an opinion paper from the Saudi Society of clinical pharmacy. Saudi Pharm J. 2020;28(8):1030-4. doi: 10.1016/i. jsps.2020.07.002, PMID 32788836.

4. Alshahrani A. Readiness of community pharmacists to play a supportive and advocacy role in the fight against coronavirus disease. Risk Manag Healthc Policy. 2020:13:3121-33. doi: 10.2147/RMHP. S282825, PMID 33380851.

5. Assiri A, lqbal MJ, Gramish J, Assiri A, Meraya A, Alhossan $A$, et al. Pharmacists' satisfaction with their involvement in the management of 
COVID-19 patients in Saudi Arabia. Saudi Pharm J. 2021;29(1):85-90. doi: 10.1016/j.jsps.2020.12.009, PMID 33437172.

6. Aburas W, Alshammari TM. Pharmacists' roles in emergency and disasters: COVID-19 as an example. Saudi Pharm J. 2020;28(12):1797-816. doi: 10.1016/j.jsps.2020.11.006, PMID 33257901.

7. Visacri MB, Figueiredo IV Lima TM. Role of pharmacist during the COVID-19 pandemic: A scoping review. Res Social Adm Pharm. 2021; 17(1):1799-806. doi: 10.1016/j.sapharm.2020.07.003. PMID 33317760

8. Alomi YA, Al-Jarallah SM. Role of Pharmacist in the epidemic, pandemic, and emergency public health with an emphasis on coronavirus Disease (COVID-19). Int J Pharmacol Clin Sci. 2021;10(1):1-5.

9. Johnston K, O'Reilly CL, Cooper G, Mitchell I. The burden of COVID-19 on pharmacists. J Am Pharm Assoc (2003). 2021;61(2):e61-4. doi: 10.1016/j. japh.2020.10.013, PMID 33189556.

10. Kristina SA, Herliana N, Hanifah S. The perception of role and responsibilities during a covid-19 pandemic: A survey from Indonesian pharmacists. Int J Pharmacol Res. 2020;12(2):3034-9.

11. ElGeed $H$, Owusu $Y$, Abdulrhim $S$, Awaisu $A$, Kattezhathu VS, Abdulrouf PV, et al. Evidence of community pharmacists' response preparedness during COVID-19 public health crisis: A crosssectional study. J Infect Dev Ctries. 2021:15(1):40-50. doi: 10.3855/jidc.13847, PMID 33571144.

12. Hope DL, Day G, Clements J, Hattingh HL. Australian community pharmacists' perceptions of public health before the COVID-19 pandemic. Int J Pharm Pract. 2021;29(3):291-5. doi: 10.1093/ ijpp/riaa010, PMID 33760912.

13. Paudyal V, Cadogan C, Fialová D, Henman MC, Hazen A, Okuyan B, et al. Provision of clinical pharmacy services during the COVID-19 pandemic: experiences of pharmacists from 16 European countries. Res Social Adm Pharm. 2021; 17(8):1507-17. doi: 10.1016/j.sapharm.2020.11.017, PMID 33288420.

14. Mukattash TL, Jarab AS, Mukattash I, Nusair MB, Farha RA, Bisharat M, et al. Pharmacists' perception of their role during covid-19: A qualitative content analysis of posts on Facebook pharmacy groups in Jordan. Pharm Pract (Granada). 2020;18(3):1900. doi: 10.18549/PharmPract.2020.3.1900, PMID 32802216

15. Al-Aqeel S, Al-Sabhan J, Al-Jumah K. A survey of psychiatrists' expectations of clinical pharmacists in Riyadh, Saudi Arabia. Med Princ Pract. 2012 Jun;21(4):383-8. doi: 10.1159/000335277, PMID 22248869

16. Tahaineh LM, Wazaify M, Albsoul-Younes A, Khader $Y$, Zaidan M. Perceptions, experiences, and expectations of physicians in hospital settings in Jordan regarding the role of the pharmacist. Res Social Adm Pharm. 2009 Mar; 5(1):63-70. doi: 10.1016/j.sapharm.2008.05.003, PMID 19285290.

17. Matowe L, Abahussain EA, Al-Saffar N, Bihzad SM, Al-Foraih A, Al-Kandery AA. Physicians' perceptions and expectations of pharmacists' professional duties in government hospitals in Kuwait.
Med Princ Pract. 2006 Apr;15(3):185-9. doi: 10.1159/000092179, PMID 16651833.

18. Khdour MR, Alayasa KS, Alshahed QN, Hawwa AF. Physicians' perceptions, attitudes and expectations regarding the role of hospital-based pharmacists in the West Bank, Palestine. Int J Pharm Pract. 2013 Jun;21(3): 178-84. doi: 10.1111/j.20427174.2012.00246.x, PMID 23418962.

19. Alipour F, Peiravian F, Mehralian G. Perceptions, experiences and expectations of physicians regarding the role of pharmacists in low-income and middle-income countries: the case of Tehran hospital settings. BMJ, (Open). 2018 Feb 1;8(2):e019237. doi: 10.1136/bmjopen-2017-019237, PMID 29420231.

20. Awad A, Matowe L, Capps P. Medical doctors' perceptions and expectations of the role of hospital pharmacists in Sudan. Pharm World Sci. 2007 Oct;29(5):557-64. doi: 10.1007/s11096-007-9111-5, PMID 17385057

21. Alomi Y, Al-Humaidan A, Alazzam A. Dentist's experiences and expectations of pharmacists in Saudi Arabia. PTB Reports. 2021;7(1):9-16. doi: 10.5530/PTB.2021.7.3.

22. Alhamad H, Abu-Farha R, Albahar $F$, Jaber D. Public perceptions about pharmacists' role in prescribing, providing education and delivering medications during COVID-19 pandemic era. Int J Clin Pract. 2021;75(4):e13890. doi: 10.1111/ ijcp.13890, PMID 33280210.

23. Charan J, Biswas T. How to calculate sample size for different study designs in medical research? Indian J Psychol Med. 2013;35(2):121-6. doi: 10.4103/0253-7176.116232, PMID 24049221.

24. Pourhoseingholi MA, Vahedi $M$, Rahimzadeh $M$. Sample size calculation in medical studies. Gastroenterol Hepatol Bed Bench. 2013;6(1):14-7. PMID 24834239.

25. Ezhumalai DG. How Big A Sample Do I Require? Annals of SBV. 2017;6(1):39-41. doi: 10.5005/ jp-journals-10085-6113.

26. Johnson TP, Wislar JS. Response rates and nonresponse errors in surveys [internet]. JAMA. 2012;307(17):1805-6. doi: 10.1001/jama.2012.3532, PMID 22550194.

27. von Elm E, Altman DG, Egger $M$, Pocock SJ, Gøtzsche PC, Vandenbroucke JP. The strengthening the reporting of observational studies in epidemiology (STROBE) statement: guidelines for reporting observational studies. PLOS Med. 2007;4(10):1623-7. doi: 10.1371/journal. pmed.0040296.

28. Von Elm E, Altman DG, Egger M, Pocock SJ, Gøtzsche PC, Vandenbroucke JP. The Strengthening the Reporting of Observational Studies in Epidemiology (STROBE) statement: guidelines for reporting observational studies [internet]. Vol. 370; 2007. Available from: http://www.thelancet.com. Available from: http://www.plosmedicine.org [cited 25/8/2021].

29. Liao D, Valliant R. Variance inflation factors in the analysis of complex survey data. Surv Methodol. 2012;38(1):53-62.
30. Akinwande MO, Dikko HG, Samson A. Variance Inflation Factor: As a Condition for the Inclusion of Suppressor Variable(s) in Regression Analysis. Open J Stat. 2015;05(07):754-67.

31. Thompson CG, Kim RS, Aloe AM, Becker BJ. Extracting the Variance In flation Factor and Other Multicollinearity Diagnostics from Typical Regression Results. Basic Appl Soc Psych. 2017:39(2):81-90.

32. Alanazi AS, Alfadl AA, Hussain AS. Pharmaceutical care in the community pharmacies of Saudi Arabia: present status and possibilities for improvement. Saudi J Med Med Sci. 2016;4(1):9-14. doi: 10.4103/1658-631X.170881, PMID 30787688.

33. Jones EJM, MacKinnon NJ, Tsuyuki RT. Pharmaceutical care in community pharmacies: practice and research in Canada. Ann Pharmacother 2005;39(9):1527-33. doi: 10.1345/aph.1E456, PMID 16014374.

34. Hughes CM, Hawwa AF, Scullin C, Anderson C,

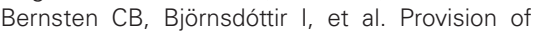
pharmaceutical care by community pharmacists: A comparison across Europe. Pharm World Sci. 2010 Aug;32(4):472-87. doi: 10.1007/s11096-0109393-x, PMID 20458539.

35. Elayeh E, Akour A, Almadaeen S, AlQhewii T, Basheti IA. Practice of pharmaceutical care in community pharmacies in Jordan. Trop J Pharm Res. 2017 Feb 1;16(2):463-70. doi: 10.4314/tjpr. v16i2.27.

36. Aloola NAI, Aljudaib S, Behery F, Alwhaibi M, Alhawassi T. Perception of Saudi community towards the transition of pharmaceutical care services from the Ministry of Health Primary Healthcare Centers to the community pharmacies. Res Sq. 2020; $12: 1-20$

37. Mohammed E, Khanal S, Jalal Z, Cheema E, Abutaleb MH, Paudyal V. Perceived barriers and facilitators to uptake of non-traditional roles by pharmacists in Saudi Arabia and implications for COVID-19 pandemic and beyond: a qualitative study using Theoretical Domain Framework. J Pharm Policy Pract. 2021;14(1):25. doi: 10.1186/ s40545-021-00307-w, PMID 33627172.

38. Auta A, Strickland-Hodge B, Maz J, David S. Pharmacist prescribing: a cross-sectional survey of the views of pharmacists in Nigeria. Int J Pharm Pract. 2018 Apr 1;26(2):111-9. doi: 10.1111/ ijpp.12381, PMID 28497878.

39. Mccann LM, Haughey SL, Parsons C, Lloyd F, Crealey G, Gormley GJ, et al. A patient perspective of pharmacist prescribing: 'crossing the specialisms crossing the illnesses' Health Expect. 2015 Feb 1;18(1):58-68. doi: 10.1111/hex.12008.

40. Gray M, Mysak T. The road to pharmacist prescribing in Alberta Health Services. Am J HealthSyst Pharm. 2016;73(18):1451-5. doi: 10.2146/ ajhp150786, PMID 27605324.

41. Al-Otaibi F, Soliman Imam M, Abdel-Sattar Ahmed RM, Alotaibi A, Alotaibi A, Alotaibi A, et al. Pharmacist privilege in Saudi Arabia: pharmacist prescribing and therapeutic interchange. PTB Reports. 2020;6(2):50-4. doi: 10.5530/PTB.2020.6.9. 